\title{
40. PETROLOGY AND GEOCHEMISTRY OF ROCKS FROM THE ANGOLA BASIN ADJACENT TO THE WALVIS RIDGE: DEEP SEA DRILLING PROJECT LEG 75, SITE 5301
}

\author{
Susan E. Humphris and Geoffrey Thompson, Chemistry Department, Woods Hole Oceanographic Institution, \\ Woods Hole, Massachusetts
}

\begin{abstract}
Deep Sea Drilling Project Leg 75 drilled into igneous basement in the Angola Basin at Site 530, located about $20 \mathrm{~km}$ north of the escarpment at the eastern end of the Walvis Ridge. Petrographic and geochemical characteristics of the basalts indicate that the basement is quite uniform, variations in chemical composition being related to weathering, crystal fractionation, and the modal abundances of individual minerals.

These basalts are similar to those drilled at Sites 527 and 528 on the central section of the Walvis Ridge, but are less enriched in incompatible elements than basalts dredged from the eastern end of the Walvis Ridge. They show distinct compositional differences from mid-ocean ridge basalts, which suggests that the Walvis Ridge hot spot has influenced the basement of the southern part of the Angola Basin. Comparison of the chemistry of Site 530 basalts with those drilled during Leg 74 indicates that the implied variation in mantle source is not in accord with any simple along-ridge progression, but may be related to vertical zonation within the volcanic pile.
\end{abstract}

\section{INTRODUCTION}

The Walvis Ridge is one of the major structural features in the South Atlantic. This aseismic ridge is believed to have originated by the passage of the African plate over a hot spot (Dietz and Holden, 1970; Morgan, 1971). The island of Tristan da Cunha is thought to be the present-day surface expression of the hot spot, and the Rio Grande Rise the western counterpart of the Walvis Ridge on the South American Plate. The Walvis Ridge is a linear feature rising more than $2 \mathrm{~km}$ above the surrounding ocean floor and extending from the MidAtlantic Ridge to the coast-line of Africa. Its SW-NE orientation and the lack of any deep passages through the Ridge limit the northward flow of bottom waters in the eastern Atlantic. Hence, the Walvis Ridge has played a major role in paleocirculation of the Atlantic Ocean, particularly for the paleoenvironments of the Angola Basin to the north of the Ridge.

During Deep Sea Drilling Project (DSDP) Leg 75, basement rocks were recovered at Site 530, located about $20 \mathrm{~km}$ north of the Walvis escarpment in the southeastern corner of the Angola Basin (Fig. 1). These provided the opportunity to investigate the geochemistry of the basalts in this area and to determine whether hot-spot volcanism, believed to have formed the Walvis Ridge, influenced the chemistry of the basement rocks in the adjacent basin.

Previous studies of the chemistry of basalts from the Walvis Ridge have shown them to be quite distinct from those erupted at the Mid-Atlantic Ridge. Basalts dredged from crust about 110 m.y. old at the eastern end of the Walvis Ridge are generally tholeiitic, but much more enriched in incompatible elements, such as $\mathrm{Ti}, \mathrm{K}, \mathrm{Sr}$, and

\footnotetext{
${ }^{1}$ Hay, W. W., Sibuet, J.-C., et al., Init. Repts. DSDP, 75: Washington (U.S. Govt. Printing Office).
}

$\mathrm{Y}$ than are mid-ocean ridge basalts (MORB) (Hekinian, 1972; Hekinian and Thompson, 1976). Further studies of rocks dredged at different locations along the Ridge have also indicated that basalts from the eastern end are characterized by $\mathrm{Zr} / \mathrm{Nb}$ ratios of about 10 , whereas MORBs generally exhibit $\mathrm{Zr} / \mathrm{Nb}$ ratios of 20 or greater (Humphris and Thompson, 1982).

Thompson and Humphris (in press) have reported on basalts from three sites drilled during DSDP Leg 74 on a segment of the Walvis Ridge about 68 to $70 \mathrm{~m}$.y. old. These drilled samples showed distinct chemical differences from MORBs and from basalts recently erupted on Tristan da Cunha. All these studies indicate that the Walvis Ridge originated from a mantle source that has differed in composition at different times in the past.

In this chapter we will discuss the petrography and chemistry of the basalts recovered from Site 530 as an indication of whether the upper basement at this location originated at the Mid-Atlantic Ridge from a mantle source producing typical mid-ocean ridge basalts, or whether the source was influenced by its proximity to the Walvis Ridge hot spot.

\section{SAMPLE LOCATIONS AND ANALYTICAL METHODS}

Hole 530A was drilled in the southeast corner of the Angola Basin in a water depth of $4629 \mathrm{~m}$. Basement was encountered at a depth of $1103 \mathrm{~m}$ below the sediment surface, and $19 \mathrm{~m}$ of basalt were penetrated. Based on paleontologic evidence, the age of the oldest sediment overlying the basement was late Albian (ca. 102.5 m.y.); this cannot be confirmed with magnetics data because the magnetic lineations are not distinct at this site. The seismic stratigraphic sequence obtained for this hole was typical for the entire deep part of the basin. In addition to the basement rock, small basaltic pebbles were found to be scattered throughout the sedimentary sequence at higher levels.

Samples of both the basement and pebbles found higher in the sedimentary sequence were obtained for study. Three pieces of rock obtained from the core catcher of Core 3 were quite distinct in appearance, and hence were designated pebbles A, B, and C, and analyzed individually. Another basaltic pebble was analyzed from lower down in the sediment sequence in Core 37. Seven samples of basalt from the $19 \mathrm{~m}$ of basement were analyzed. 


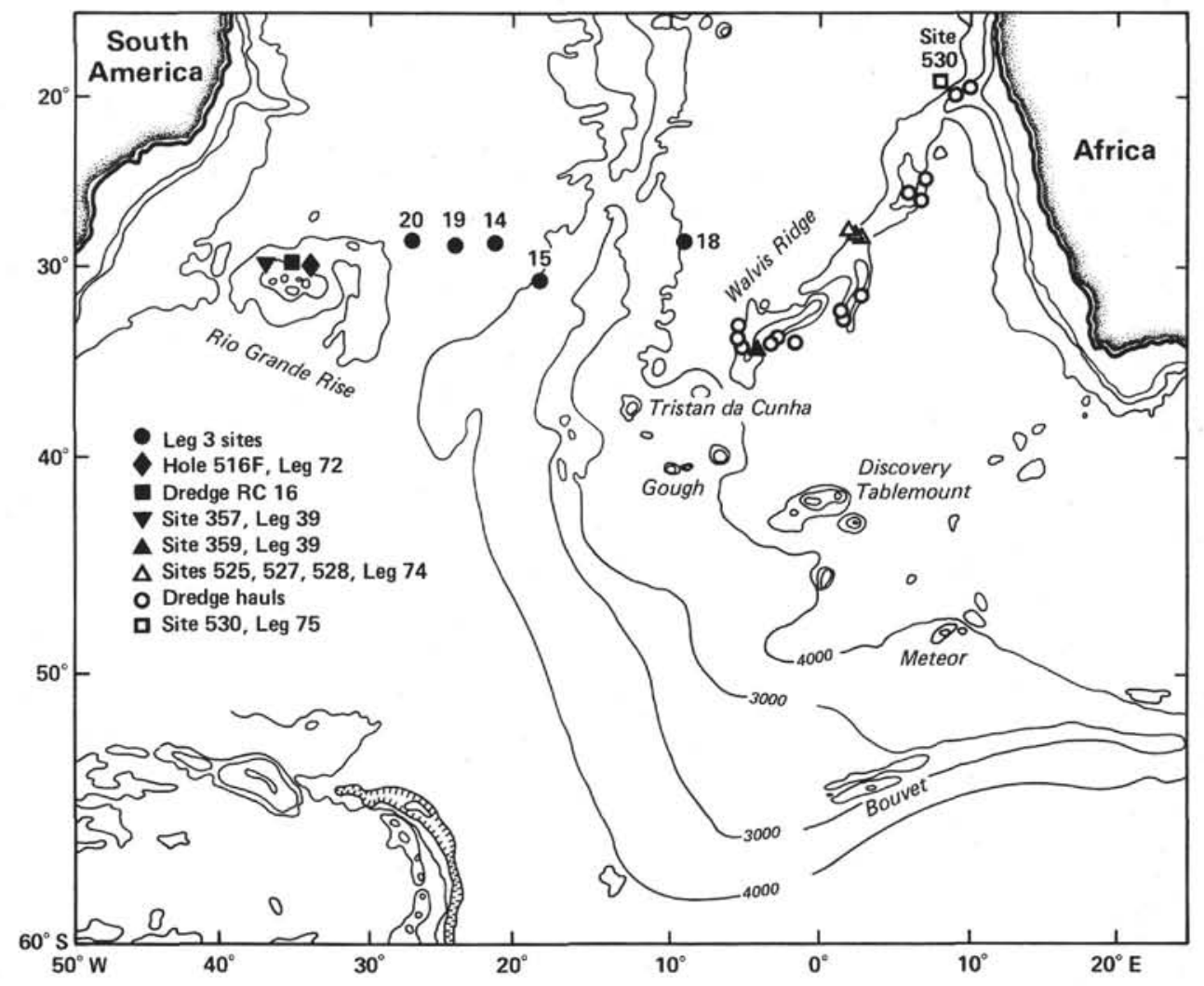

Figure 1. Map of the South Atlantic showing location of DSDP Site 530. Other DSDP sites and dredge hauls on the Walvis Ridge and Rio Grande Rise are also shown.

The samples were analyzed for major and trace elements by X-ray fluorescence spectrometry using the technique of Schroeder et al. (1980). Precision and accuracy for the major elements are between \pm 1 and $3 \%$ and about $\pm 5 \%$ for the trace elements. Ferrous iron concentrations were determined by titration (Jen, 1973), and $\mathrm{H}_{2} \mathrm{O}^{+}$and $\mathrm{CO}_{2}$ were analyzed using a Perkin Elmer 240B CHN analyzer (Skinner et al., 1981).

\section{PETROGRAPHY}

The basalts recovered from the basement of Hole $530 \mathrm{~A}$ are quite similar in their phenocryst and microphenocryst assemblages, the major differences being textural. Individual flow units cannot be defined from the samples studied, although one glassy margin was identified by the shipboard party. Textures vary from a quenched basalt with microlites disseminated throughout a glassy matrix (e.g., Sample 530A-107-2, 41-43 cm) to more crystalline samples in which phenocrysts and microphenocrysts occur in an intergranular matrix (e.g., Sample 530A-107-1, 48-50 cm). Vesicles are uncommon, suggesting that the unit was erupted in deep water.

Mineralogically, the basalts are composed dominantly of plagioclase, pyroxene, and iron oxides. Rare euhedral pyroxene phenocrysts up to $2 \mathrm{~mm}$ long, and occasional large euhedral plagioclase phenocrysts up to 1 $\mathrm{mm}$ long, occur in a few samples (e.g., Samples 530A$107-1,48-50 \mathrm{~cm}$; $530 \mathrm{~A}-108-2,10-12 \mathrm{~cm}$; and 530A-108$2,105-107 \mathrm{~cm})$. However, more typically, plagioclase, often in the form of laths, and euhedral to subhedral pyroxene microphenocrysts occur together as glomerocrysts (e.g., Samples 530A-107-2, 41-43 cm and 530A-
$108-1,44-46 \mathrm{~cm}$ ). The groundmass generally consists of randomly oriented microlites of plagioclase and intergranular pyroxene in a fine-grained to glassy matrix. A noticeable feature is the presence of iron oxides (a few percent by volume) scattered throughout the matrix in the basement samples studied.

All of the samples are weathered to some degree. Partial replacement of some microphenocrysts by calcite, and amygdales filled with calcite, are common, particularly in the more weathered samples (e.g., Sample 530A$107-2,41-43 \mathrm{~cm}$ ). Brown and green clay minerals, together with calcite, have replaced patches of what might have originally been glass in the matrix.

The basaltic basement at this site therefore differs markedly from typical MORB. Mineralogically, the basalts resemble more closely both dredged and drilled samples recovered from the Walvis Ridge (e.g., Hekinian, 1972; Humphris and Thompson, 1982; Thompson and Humphris, in press), particularly in their pyroxene and iron oxide contents.

The basaltic pebbles from higher up in the hole that were recovered in sections of the sedimentary sequence are quite variable petrographically. The three corecatcher samples are totally different from each other. Sample 530A-3,CC (Pebble A) appears to be composed of a few anhedral pyroxene and plagioclase crystals cemented together by calcite. No small pieces of basalt were observed in thin section. Sample 530A-3, CC (Pebble B) is a highly weathered, fine-grained, aphyric basalt, consisting of thin plagioclase laths, numerous small 
grains of iron oxides, and considerable alteration of the rest of the matrix to calcite and green clay minerals. Sample 530A-3,CC (Pebble C) is an almost holocrystalline basalt consisting dominantly of euhedral or lathlike plagioclase with intergranular pyroxene and aggregations of large grains of iron oxides. Patchy weathering to a green clay mineral has also occurred.

The sample from Core 37 (Sample 530A-37-3, 100-104 $\mathrm{cm}$ ) is a piece of highly weathered basalt penetrated by large calcite veins, and with numerous amygdales filled with calcite. Minerals that can still be identified include laths of plagioclase and grains of iron oxides in a brown, highly weathered matrix. There is also evidence of a mineral exhibiting high birefringence and oblique extinction, which might possibly have been pyroxene.

All of these basaltic pebbles are probably derived from the adjacent Walvis Ridge. The sedimentary column shows evidence of slumping of material from the flanks of the Ridge, and it is probable that some volcanics were also moved downslope. In addition, the possibility exists that the pebbles fell into the hole during drilling and were actually deposited higher in the sequence. Hence, it is not possible to derive with certainty any information on the origin or age of these pebbles from their location within the sedimentary stratigraphic sequence.

\section{CHEMISTRY}

\section{Within Site Variations}

\section{Basement Rocks}

Major and trace element analyses of samples from Cores 107 and 108 are presented in Table 1 and indicate that all the basalts are geochemically similar. The only minor differences are seen in the two samples from Section 108-2; their slightly lower concentrations of $\mathrm{TiO}_{2}$, $\mathrm{Na}_{2} \mathrm{O}, \mathrm{V}$, and $\mathrm{Zr}$ suggest that they might be slightly less evolved than the overlying basement. However, the apparent depletion in these elements is accompanied by higher concentrations of $\mathrm{K}_{2} \mathrm{O}$ and $\mathrm{Rb}$ and quite variable $\mathrm{Cr}, \mathrm{Co}$, and Ni contents. Some of these differences are shown in Figure 2. It should be emphasized that the differences between Section 108-2 and the overlying basalt are quite small and, in addition, that both of these samples are more crystalline than any other samples studied. Many of the trends seen in Figure 2 can be accounted for by differences in the degree of crystal fractionation and the modal content of individual minerals. Subsequent weathering has also affected the chemical composition of the basalts, notably the $\mathrm{K}_{2} \mathrm{O}$ and $\mathrm{Rb}$ concentrations. Since all the samples are so geochemically similar, it is possible to represent the basement at Hole 530A by an average chemical composition for comparison with rocks from other parts of the South Atlantic.

\section{Basaltic Pebbles}

Major and trace element analyses of the pieces of basalt recovered during drilling in the overlying sediment are shown in Table 2 . All of them are geochemically distinct from each other and from the basement at this site.
Table 1. Major and trace element analyses of basalts, Hole 530A.

\begin{tabular}{|c|c|c|c|c|c|c|c|}
\hline \multirow[b]{2}{*}{ Component } & \multicolumn{5}{|c|}{$\begin{array}{c}\text { Sample } \\
\text { (interval in } \mathrm{cm} \text { ) }\end{array}$} & \multirow[b]{2}{*}{$\begin{array}{l}108-2 \\
10-12\end{array}$} & \multirow[b]{2}{*}{$\begin{array}{c}108-2 \\
105-107\end{array}$} \\
\hline & $\begin{array}{l}107-1 \\
48-50\end{array}$ & $\begin{array}{l}107-2 \\
41-44\end{array}$ & $\begin{array}{c}107-2 \\
142-144\end{array}$ & $\begin{array}{l}107-3 \\
27-29\end{array}$ & $\begin{array}{l}108-1 \\
44-46\end{array}$ & & \\
\hline \multicolumn{8}{|c|}{ Major element oxides $(w t . \%)^{\mathrm{a}}$} \\
\hline $\mathrm{SiO}_{2}$ & 49.98 & 49.36 & 49.72 & 49.68 & 50.15 & 49.23 & 49.89 \\
\hline $\mathrm{TiO}_{2}$ & 1.90 & 1.85 & 1.86 & 1.76 & 1.86 & 1.70 & 1.72 \\
\hline $\mathrm{Al}_{2} \mathrm{O}_{3}$ & 16.52 & 16.48 & 16.25 & 15.52 & 16.14 & 15.44 & 15.99 \\
\hline $\mathrm{FeO}^{*}$ & 9.61 & 9.91 & 9.58 & 10.35 & 9.62 & 10.75 & 10.54 \\
\hline $\mathrm{MnO}$ & 0.31 & 0.32 & 0.30 & 0.30 & 0.28 & 0.25 & 0.24 \\
\hline $\mathrm{MgO}$ & 8.38 & 7,48 & 8.21 & 7.82 & 8.39 & 8.08 & 8.05 \\
\hline $\mathrm{CaO}$ & 10.02 & 10.90 & 10.59 & 11.29 & 10.74 & 10.68 & 10.11 \\
\hline $\mathrm{Na}_{2} \mathrm{O}$ & 2.81 & 2.78 & 2.74 & 2.65 & 2.77 & 2.42 & 2.52 \\
\hline $\mathrm{K}_{2} \mathrm{O}$ & 0.09 & 0.35 & 0.10 & 0.36 & 0.10 & 0.54 & 0.55 \\
\hline $\mathrm{P}_{2} \mathrm{O}_{5}$ & 0.28 & 0.25 & 0.26 & 0.23 & 0.25 & 0.26 & 0.26 \\
\hline Total & 99.90 & 99.68 & 99.61 & 99.96 & 100.30 & 99.35 & 99.86 \\
\hline \multicolumn{8}{|l|}{ Other analyses } \\
\hline $\mathrm{FeO}$ & 4.15 & 4.15 & 4.35 & 4.54 & 4.35 & 4.51 & 4.31 \\
\hline $\mathrm{Fe}_{2} \mathrm{O}_{3}$ & 6.07 & 6.40 & 5.81 & 6.46 & 5.86 & 6.93 & 6.92 \\
\hline $\mathrm{H}_{2} \mathrm{O}^{+}$ & 1.49 & 1.55 & 0.81 & 1.26 & 1.28 & 1.42 & 1.58 \\
\hline $\mathrm{H}_{2} \mathrm{O}^{-}$ & 3.16 & 4.32 & 2.51 & 2.85 & 2.96 & 2.58 & 3.45 \\
\hline $\mathrm{CO}_{2}$ & 0.20 & 1.42 & 0.21 & 0.87 & 0.15 & 0.22 & 0.20 \\
\hline \multicolumn{8}{|c|}{ Trace elements (ppm) ${ }^{b}$} \\
\hline $\mathrm{Rb}$ & 1.9 & 8.1 & 1.5 & 10.1 & 1.9 & 15.4 & 15.8 \\
\hline V & 355 & 337 & 342 & 319 & 341 & 302 & 312 \\
\hline $\mathrm{Cr}$ & 91 & 90 & 84 & 86 & 89 & 94 & 91 \\
\hline Co & 46 & 72 & 42 & 46 & 44 & 33 & 39 \\
\hline $\mathrm{Ni}$ & 74 & 124 & 70 & 81 & 73 & 66 & 79 \\
\hline $\mathrm{Cu}$ & 68 & 69 & 69 & 65 & 68 & 73 & 71 \\
\hline $\mathrm{Zn}$ & 77 & 84 & 79 & 75 & 76 & 72 & 73 \\
\hline $\mathrm{Sr}$ & 285 & 265 & 267 & 255 & 271 & 257 & 274 \\
\hline $\mathrm{Ba}$ & 119 & 149 & 121 & 124 & 133 & 122 & 146 \\
\hline $\mathrm{Y}$ & 36 & 32 & 37 & 34 & 38 & 32 & 30 \\
\hline $\mathrm{Zr}$ & 139 & 131 & 134 & 131 & 135 & 127 & 128 \\
\hline $\mathrm{Nb}$ & 21.2 & 20.5 & 20.7 & 20.7 & 20.2 & 20.7 & 21.2 \\
\hline
\end{tabular}

a Volatile-free basis after ignition at $1000^{\circ} \mathrm{C}$.

$b^{b}$ Dried at $110^{\circ} \mathrm{C}$.

They are highly weathered and contain over $4.8 \mathrm{wt} . \%$ $\mathrm{H}_{2} \mathrm{O}$; hence, any compositional comparisons have to be limited to elements least affected by weathering. The chemical composition obtained for Pebble A is clearly dominated by calcium carbonate and hence has not been used in any further discussion. The analysis total for Pebble B is very low, probably as a result of the high degree of weathering exhibited by replacement of groundmass by clay minerals and calcite. Pebble $\mathrm{C}-$ the most crystalline of all-differs markedly from the underlying basement, having higher concentrations of $\mathrm{Zr}, \mathrm{Ba}, \mathrm{Sr}$, and $\mathrm{Rb}$, and lower $\mathrm{Nb}, \mathrm{Y}, \mathrm{Cu}, \mathrm{Ni}, \mathrm{Cr}$, and $\mathrm{V}$ contents. Its $\mathrm{FeO}^{*} / \mathrm{MgO}$ ratio is also higher (1.61) than in the basement rocks. Some of these differences can be explained by the dominance of plagioclase in this sample; however, the variations in the incompatible elements, particularly $\mathrm{Zr}, \mathrm{Y}$, and $\mathrm{Nb}$, suggest that this sample is unrelated to that recovered in Cores 107 and 108.

Sample 530A-37-3 is also chemically distinct, exhibiting a very high $\mathrm{TiO}_{2}$ content (3.14 wt.\%), an FeO*/ $\mathrm{MgO}$ ratio of 1.97 , and high concentrations of $\mathrm{Zr}$ and $\mathrm{Nb}$, compared with the other basalts recovered from this hole.

\section{Regional Geochemical Comparison}

Table 3 presents some average compositions of previously analyzed basalts from the Walvis Ridge, the Rio Grande Rise, Tristan da Cunha, and the Mid-Atlantic Ridge at this latitude. Based on their overall chemistry, 

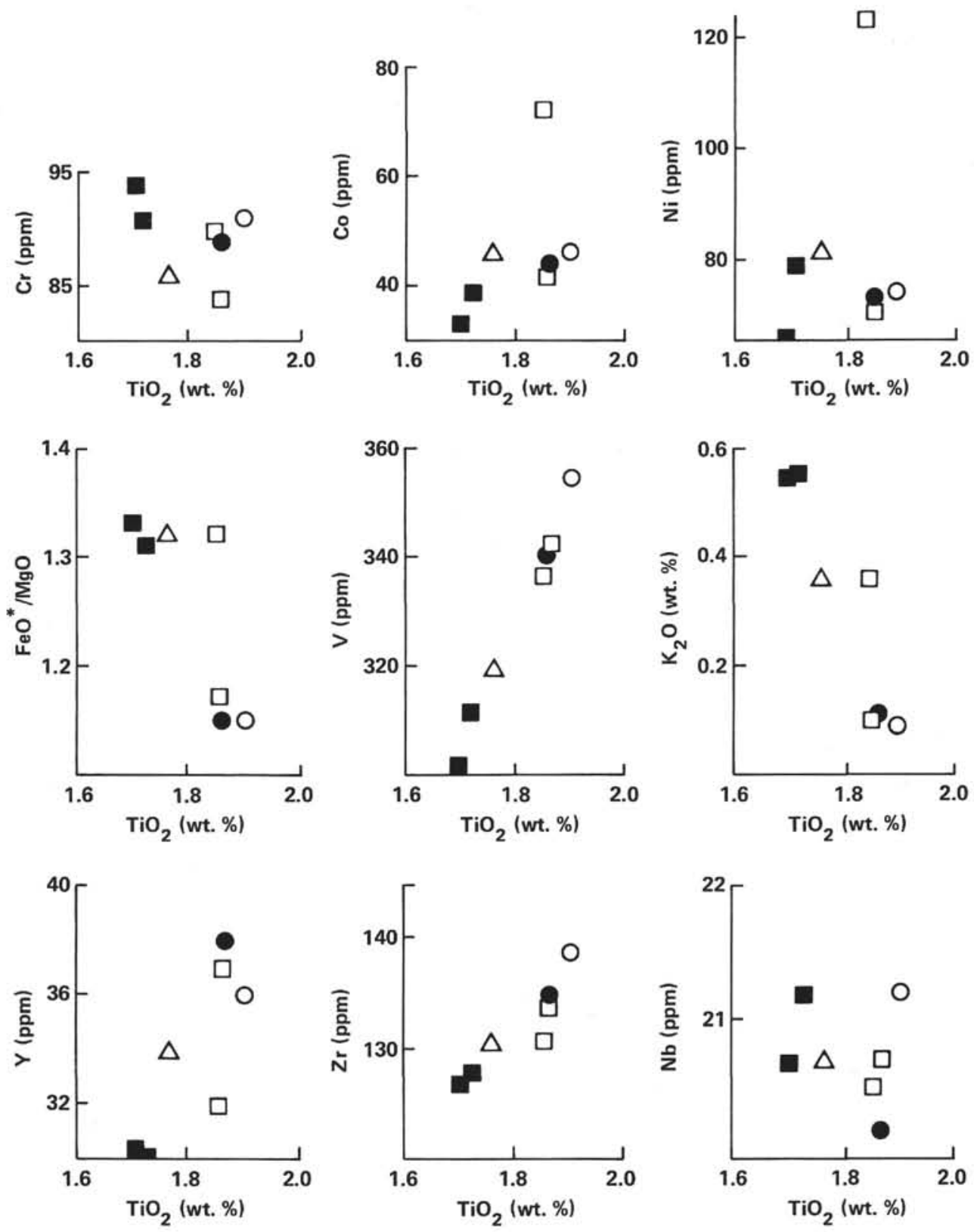

Leg 75, Hole 530A

O Section 107-1 $\square$ Section 107-2 $\triangle$ Section 107-3

Figure 2. Plots of selected major-element oxides and trace elements versus $\mathrm{TiO}_{2}$ for the basement rocks at Hole 530A.

the Site 530 basement basalts are quite distinct from the Mid-Atlantic Ridge basalts that were drilled at about $30^{\circ} \mathrm{S}$ and range in age up to $50 \mathrm{~m}$.y. (Frey et al., 1974). However, they are quite similar to basalts drilled during Leg 74 on the Walvis Ridge, in particular the basement at Sites 527 and 528, both located on the northwestern flank of the central section of the Ridge (see Fig. 1). They are not as enriched in incompatible elements as are basalts from other parts of the Walvis Ridge, Tristan da Cunha, or the Rio Grande Rise.

Comparison of the chemical compositions of the basaltic pebbles recovered from the sediments with the average analyses for rocks from the Walvis Ridge sug- gest similarities. They are both enriched in incompatible elements and fall within the range of compositions previously observed on the Ridge (Humphris and Thompson, 1982).

On an alkalis-silica diagram (Fig. 3), all the Hole $530 \mathrm{~A}$ basement basalts plot in the field of Hawaiian tholeiites and, more specifically, in the field of basalts from DSDP Leg 74, Sites 527 and 528. The field for basalts dredged from the Walvis Ridge extends across the tholeiitic-alkaline boundary, and two of the pebblesSamples 530A-3,CC (Pebble C) and 530A-37-3-plot within this field, one on either side of the boundary. Hence, although the Hole 530A basement rocks are no- 
Table 2. Major and trace element analyses of basaltic pebbles recovered from sedimentary sequence.

\begin{tabular}{|c|c|c|c|c|}
\hline \multirow[b]{2}{*}{ Component } & \multicolumn{3}{|c|}{ Sample 530A-3,CC } & \multirow{2}{*}{$\begin{array}{c}\text { Section 530A- } \\
37-3\end{array}$} \\
\hline & Pebble A & Pebble B & Pebble C & \\
\hline \multicolumn{5}{|c|}{ Major elements (wt. \%) ${ }^{\mathrm{a}}$} \\
\hline $\mathrm{SiO}_{2}$ & 29.74 & 49.38 & 52.85 & 45.40 \\
\hline $\mathrm{TiO}_{2}$ & 2.45 & 2.07 & 1.91 & 3.14 \\
\hline $\mathrm{Al}_{2} \mathrm{O}_{3}$ & 8.26 & 14.47 & 15.97 & 14.66 \\
\hline $\mathrm{FeO}^{*}$ & 8.35 & 7.80 & 8.96 & 11.02 \\
\hline $\mathrm{MnO}$ & 0.18 & 0.10 & 0.10 & 0.11 \\
\hline $\mathrm{MgO}$ & 6.05 & 3.66 & 5.56 & 5.59 \\
\hline $\mathrm{CaO}$ & 33.52 & 7.67 & 9.44 & 14.46 \\
\hline $\mathrm{Na}_{2} \mathrm{O}$ & 1.65 & 1.79 & 2.37 & 3.06 \\
\hline $\mathrm{K}_{2} \mathrm{O}$ & 1.47 & 6.35 & 1.37 & 1.03 \\
\hline $\mathrm{P}_{2} \mathrm{O}_{5}$ & 1.19 & 1.61 & 0.22 & 0.21 \\
\hline Total & 92.86 & 94.90 & 98.75 & 98.68 \\
\hline \multicolumn{5}{|c|}{ Other analyses } \\
\hline $\mathrm{FeO}$ & 3.85 & 3.16 & 4.05 & 2.34 \\
\hline $\mathrm{Fe}_{2} \mathrm{O}_{3}$ & 5.00 & 5.16 & 5.46 & 9.65 \\
\hline $\mathrm{H}_{2} \mathrm{O}^{+}$ & 3.06 & 2.75 & 1.49 & 2.17 \\
\hline $\mathrm{H}_{2} \mathrm{O}^{-}$ & 6.75 & 5.90 & 3.39 & 3.93 \\
\hline $\mathrm{CO}_{2}$ & 20.79 & 3.66 & 0.17 & 5.49 \\
\hline \multicolumn{5}{|c|}{ Trace elements (ppm) ${ }^{\mathrm{b}}$} \\
\hline $\mathrm{Rb}$ & 18.5 & 56.0 & 39.6 & 18.1 \\
\hline V & 73 & 144 & 232 & 213 \\
\hline $\mathrm{Cr}$ & 286 & 309 & 51 & 189 \\
\hline Co & 30 & 29 & 31 & 58 \\
\hline $\mathrm{Ni}$ & 133 & 103 & 48 & 201 \\
\hline $\mathrm{Cu}$ & 33 & 47 & 39 & 42 \\
\hline $\mathrm{Zn}$ & 60 & 66 & 74 & 307 \\
\hline $\mathrm{Sr}$ & 226 & 220 & 344 & 492 \\
\hline $\mathrm{Ba}$ & 1682 & 4218 & 424 & 239 \\
\hline $\mathrm{Y}$ & 26 & 60 & 27 & 26 \\
\hline $\mathrm{Zr}$ & 117 & 143 & 152 & 219 \\
\hline $\mathrm{Nb}$ & 24.2 & 49.6 & 13.6 & 44.2 \\
\hline
\end{tabular}

a Volatile-free basis after ignition at $1000^{\circ} \mathrm{C}$.

$\mathrm{b}$ Dried at $110^{\circ} \mathrm{C}$.

ticeably enriched in incompatible elements compared with mid-ocean ridge basalts, they do not show such marked alkaline affinities as the dredged Walvis Ridge basalts.

This is further illustrated in Figure 4, a plot of $\mathrm{TiO}_{2}$ versus $\mathrm{Zr}$ concentrations, in which the Leg 75 data are plotted together with fields for other analyzed basalts from the region. The basement basalt and the Core 3 pebble are enriched in these elements compared with MORBs, but do not exhibit the large enrichments displayed by the dredged Walvis Ridge basalts, the Rio Grande Rise basalts, and Tristan da Cunha basalts. DSDP Leg 74 Sites 527 and 528 also fall in this intermediate range of enrichments.

Figure 5 shows a plot of $\mathrm{Nb}$ versus $\mathrm{Zr}$ concentrations, the ratio of which is a good indicator of the source region of the basalt (Erlank and Kable, 1976). Humphris and Thompson (1982) and Thompson and Humphris (in press) have previously used this ratio to demonstrate systematic changes in the mantle source for the Walvis Ridge with time, illustrated by the large variations in the $\mathrm{Zr} / \mathrm{Nb}$ ratio. MORBs, with $\mathrm{Zr} / \mathrm{Nb}$ ratios of greater than 20 , represent one end member; the other is Tristan da
Cunha basalts with $\mathrm{Zr} / \mathrm{Nb}$ ratios of about 3.5. The compositions of Walvis Ridge and Rio Grande Rise basalts cannot easily be derived by mixing of these two end members (Humphris and Thompson, 1982). Hence, they concluded that the Walvis Ridge was probably derived from mantle sources of variable composition.

The basement rocks from Site 530 are characterized by a $\mathrm{Zr} / \mathrm{Nb}$ ratio of $6-7$. They plot on the same line as do Sites 527 and 528, both drilled on the central section of the Walvis Ridge, and as dredged basalts from the central section of the Ridge. This suggests that the basement in the Angola Basin adjacent to the eastern end of the Walvis Ridge was derived from a mantle source similar to that which produced the basalts found in the Central Section. Basalts dredged from the eastern end of the Walvis Ridge are characterized by $\mathrm{Zr} / \mathrm{Nb}$ ratios of 10 , which indicates a different mantle source. Basaltic Pebble $\mathrm{C}$ from Core 3 has a $\mathrm{Zr} / \mathrm{Nb}$ ratio of 11 and hence is quite probably derived from slumping along the northern flank of the eastern end of the Walvis Ridge.

These data therefore indicate that the hot spot that created the Walvis Ridge has influenced the basement characteristics at least out to $20 \mathrm{~km}$ north of the feature itself. The full lateral extent of the hot spot influence, however, cannot be determined at present, although the similarity of the seismic stratigraphic sequence at Hole $530 \mathrm{~A}$ to that for the entire deep part of the Angola Basin suggests that it may extend for several hundred $\mathrm{km}$. The present-day hot spot, centered at Tristan da Cunha, about $400 \mathrm{~km}$ from the axis of the Mid-Atlantic Ridge, has been shown to influence the geochemical characteristics of basalts erupting at the mid-ocean ridge (Schilling et al., 1981). Basalts recovered from the Mid-Atlantic Ridge at about $37^{\circ} \mathrm{S}$ are slightly enriched in incompatible elements compared with typical MORB's, and have $\mathrm{Zr} / \mathrm{Nb}$ ratios of 14-16. Hence, a large area of influence for a hot spot may not be unreasonable.

These data also have important implications concerning the origin of the Walvis Ridge. They provide additional evidence that the Ridge was derived from mantle sources with different $\mathrm{Zr} / \mathrm{Nb}$ ratios. However, it is now clear that the variation is not a simple along-ridge (i.e., time) progression, but is more complex. The basement at Site 530 (84-102 m.y.), north of the eastern end of the Walvis Ridge, is geochemically similar to the basement drilled during DSDP Leg 74 at Sites 527 and 528 (both about $68 \mathrm{~m}$.y.) on the central section of this Ridge. This suggests that, unlike other hot spots, volcanism produced basalts with similar geochemical characteristics continuously over a period of at least $20 \mathrm{~m}$.y. However, there is also a smaller scale variation evident in that basalts from Site 525, drilled on the crest of the Ridge, are unlike those from Sites 527, 528, and 530. Comparison of the water depths at Sites 525, 527, and 528 (2467, 4428 , and $3800 \mathrm{~m}$, respectively) with that at Site 530 $(4629 \mathrm{~m})$ suggests that there may be a vertical zonation within the volcanic pile, similar to that seen on volcanic islands, with the erupted basalts becoming more alkaline and more enriched in incompatible elements towards the crest. Rare-earth elements and isotopic data will be needed to test this hypothesis further. 
Table 3. Comparative average analyses of basalts from the Rio Grande Rise, Walvis Ridge, Tristan da Cunha, Site 530, and the MidAtlantic Ridge.

\begin{tabular}{|c|c|c|c|c|c|c|c|c|c|}
\hline \multirow[b]{2}{*}{ Component } & \multicolumn{2}{|c|}{ Rio Grande Rise } & \multicolumn{4}{|c|}{ Walvis Ridge } & \multirow[b]{2}{*}{$\begin{array}{c}\text { Tristan da } \\
\text { Cunhag }\end{array}$} & \multirow[b]{2}{*}{$\begin{array}{l}\text { Leg } 75 \\
\text { Site } 530^{h}\end{array}$} & \multirow[b]{2}{*}{$\begin{array}{c}\text { Mid-Atlantic } \\
\text { Ridge, S. Atlantic }\end{array}$} \\
\hline & $\begin{array}{c}\text { Leg } 72 \\
\text { Hole } 516 \mathrm{~F}^{\mathrm{a}}\end{array}$ & $\begin{array}{l}\text { Dredge } \\
\mathrm{RCl}^{6}\end{array}$ & $\begin{array}{l}\text { E. Walvis } \\
\text { Ridge }^{c}\end{array}$ & $\begin{array}{l}\text { Leg } 74 \\
\text { Site } 525^{\mathrm{d}}\end{array}$ & $\begin{array}{l}\text { Leg } 74 \\
\text { Site } 527^{\mathrm{e}}\end{array}$ & $\begin{array}{l}\text { Leg } 74 \\
\text { Site } 528 \mathrm{f}\end{array}$ & & & \\
\hline \multicolumn{6}{|c|}{ Major element oxides (wt.\%) } & & & & \\
\hline $\mathrm{SiO}_{2}$ & 50.48 & 47.33 & 51.14 & 52.17 & 50.10 & 49.99 & 46.7 & 49.72 & 50.74 \\
\hline $\mathrm{TiO}_{2}$ & 2.51 & 3.25 & 3.03 & 2.92 & 1.83 & 1.93 & 3.6 & 1.81 & 1.03 \\
\hline $\mathrm{Al}_{2} \mathrm{O}_{3}$ & 15.12 & 14.90 & 16.53 & 17.92 & 15.33 & 16.46 & 17.3 & 16.05 & 15.83 \\
\hline $\mathrm{FeO}^{*}$ & 12.76 & 9.60 & 11.96 & 9.11 & 12.06 & 11.02 & 10.4 & 10.05 & 9.05 \\
\hline $\mathrm{MnO}$ & 0.17 & 0.17 & & 0.08 & 0.19 & 0.20 & & 0.29 & 0.15 \\
\hline $\mathrm{MgO}$ & 5.23 & 7.19 & 2.37 & 3.49 & 6.40 & 6.26 & 4.7 & 8.06 & 8.78 \\
\hline $\mathrm{CaO}$ & 10.61 & 10.15 & 7.08 & 8.64 & 10.38 & 9.98 & 9.7 & 10.62 & 12.20 \\
\hline $\mathrm{Na}_{2} \mathrm{O}$ & 2.61 & 3.57 & 2.91 & 3.42 & 2.67 & 2.82 & 4.1 & 2.67 & 2.32 \\
\hline $\mathrm{K}_{2} \mathrm{O}$ & 0.28 & 1.73 & 2.19 & 0.94 & 0.59 & 1.01 & 3.0 & 0.30 & 0.06 \\
\hline $\mathrm{P}_{2} \mathrm{O}_{5}$ & 0.21 & 0.75 & & 0.30 & 0.25 & 0.28 & & 0.26 & \\
\hline \multicolumn{10}{|c|}{ Trace elements (ppm) } \\
\hline $\mathrm{Rb}$ & 6.5 & 2.8 & & 15 & 11 & 16 & 173 & 8 & \\
\hline V & 380 & 271 & 437 & 353 & 360 & 366 & 230 & 330 & 233 \\
\hline $\mathrm{Cr}$ & 32 & 146 & 73 & 139 & 45 & 35 & 28 & 89 & 500 \\
\hline Co & 49 & 45 & 62 & 62 & 42 & 43 & 18 & 46 & 49 \\
\hline $\mathrm{Ni}$ & 52 & 106 & 55 & 53 & 45 & 42 & 10 & 81 & 174 \\
\hline $\mathrm{Cu}$ & 198 & 55 & 110 & 79 & 142 & 113 & & 69 & 102 \\
\hline $\mathrm{Zn}$ & 112 & 103 & & 139 & 80 & 79 & & 77 & \\
\hline $\mathrm{Sr}$ & 360 & 928 & 318 & 482 & 159 & 302 & 1167 & 268 & 124 \\
\hline $\mathrm{Ba}$ & 176 & 1156 & 384 & 403 & 197 & 350 & 913 & 131 & 13 \\
\hline $\mathrm{Y}$ & 38 & 25 & 46 & 37 & 39 & 35 & 45 & 34 & 35 \\
\hline $\mathrm{Zr}$ & 180 & 293 & 200 & 251 & 125 & 142 & 325 & 132 & 91 \\
\hline $\mathrm{Nb}$ & 13.7 & 70 & 20 & 23 & 17 & 24 & 112 & 21 & $<5$ \\
\hline
\end{tabular}

Note: Blank spaces $=$ not analyzed.

a Ave, of 13 basalts (Thompson et al., in press).

b Mean of 3 basalts (Fodor et al., 1977).

C Mean of 7 basalts (Hekinian, 1972; Hekinian and Thompson, 1976).

d Ave. of 13 basalts (Thompson and Humphris, in press).

e Ave. of 6 basalts (Thompson and Humphris, in press).

Ave, of 10 basalts (Thompson and Humphris, in press)

$g$ Ave. of 10 analyses (Baker et al., 1964).

$h$ Ave of 7 basalts (this chapter, Table 1).

${ }^{i}$ Ave, of 7 basalt glass analyses, DSDP Leg 3 (Frey et al., 1974).

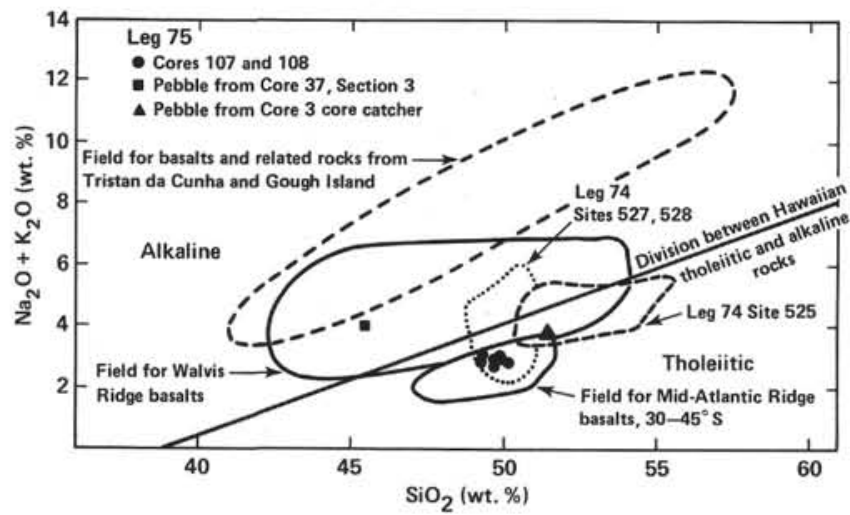

Figure 3. Alkalis-silica diagram showing the fields of alkaline and tholeiitic basalts (after MacDonald and Katsura, 1964). The field for basalts from Tristan da Cunha is from data of Baker et al. (1964) and Humphris and Thompson (1982); the data for the Walvis Ridge dredged basalts are from Hekinian (1972) and Humphris and Thompson (1982); the data for Leg 74 are from Thompson and Humphris (in press); and the data for Mid-Atlantic Ridge basalts are from Frey et al. (1974), Humphris and Thompson (1982), Schilling et al. (1981).

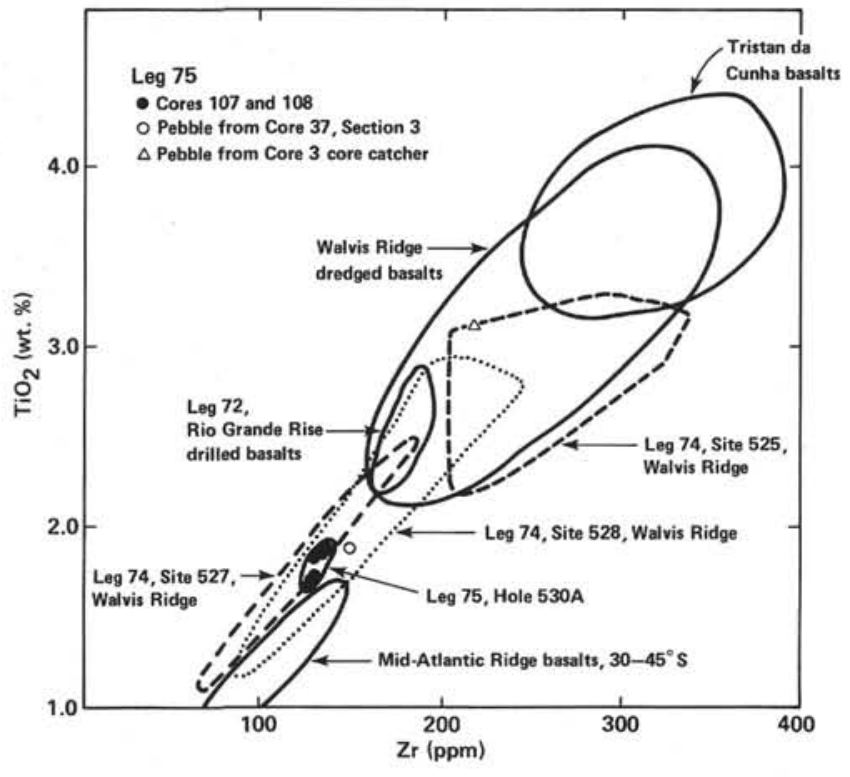

Figure 4. Plot of $\mathrm{TiO}_{2}$ versus $\mathrm{Zr}$ for Hole $530 \mathrm{~A}$ and other basalts. Data sources as in Figure 3, with data for Rio Grande Rise from Thompson et al., in press. 


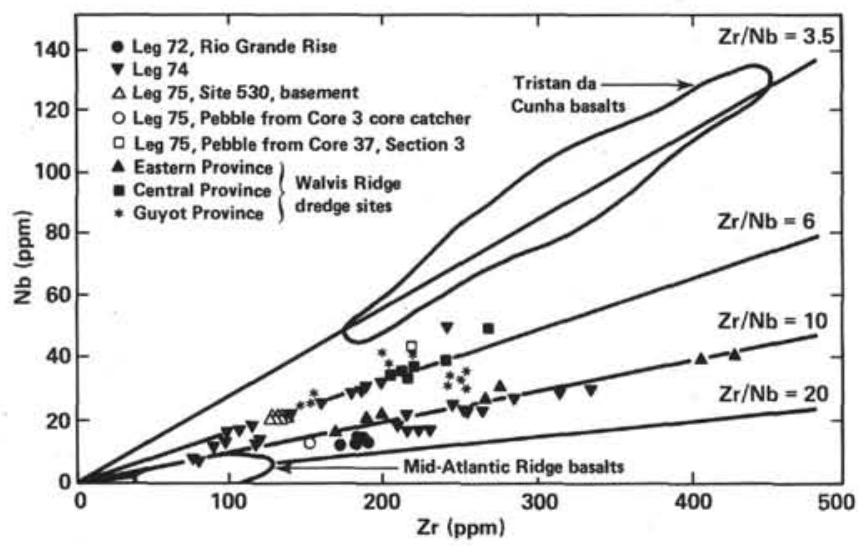

Figure $5 . \mathrm{Nb}$ versus $\mathrm{Zr}$ concentrations in basalts from Hole 530A, and other areas. Data for Tristan da Cunha and the Walvis Ridge are from Humphris and Thompson (1982); the other sources are as in Figure 3.

\section{ACKNOWLEDGMENTS}

We gratefully acknowledge access to Leg 75 samples by the DSDP. Thanks are due to Margaret Sulanowska, Brian Schroeder, and Don Bankston for their help in the laboratory. This work was supported by NSF grant OCE-80-24629. This is contribution no. 5152 of the Woods Hole Oceanographic Institution.

\section{REFERENCES}

Baker, P. E., Gass, I. G., Harris, P. G., and le Maitre, R. W., 1964. The volcanological report of the Royal Society expedition to Tristan da Cunha, 1962. Phil. Trans. Roy. Soc. London A, 256: 439-575.

Dietz, R. S., and Holden, J. C., 1970. Reconstruction of Pangaea: Spreading and dispersion of continents, Permian to Recent. $J$. Geophys. Res., 75:4939-4956.

Erlank, A. J., and Kable, E. J. D., 1976. The significance of incompatible elements in Mid-Atlantic Ridge basalts from $45^{\circ} \mathrm{N}$ with particular reference to $\mathrm{Zr} / \mathrm{Nb}$. Contrib. Mineral. Petrol., 54: 281-291.

Fodor, R. V., Husler, J. W., and Kumar, N., 1977. Petrology of volcanic rocks from an aseismic rise: Implications for the origin of the Rio Grande Rise, South Atlantic Ocean. Earth Planet. Sci. Lett., 35:225-233.

Frey, F. A., Bryan, W. B., and Thompson, G., 1974. Atlantic Ocean floor: Geochemistry and petrology of basalts from Legs 2 and 3 of the Deep Sea Drilling Project. J. Geophys. Res., 79:5507-5527.

Hekinian, R., 1972. Volcanics from the Walvis Ridge in the Southeast Atlantic Ocean. Nature, 239:91-93.

Hekinian, R., and Thompson, G., 1976. Comparative geochemistry of volcanics from rift valleys, transform faults, and aseismic ridges. Contr. Mineral. Petrol., 57:145-162.

Humphris, S. E., and Thompson, G., 1982. A geochemical study of rocks from the Walvis Ridge, South Atlantic. Chem. Geol., 36: 253-274.

Jen, L. A., 1973. The determination of iron (11) in silicate rocks and minerals. Anal. Chim. Acta, 66:315-318.

MacDonald, G. A., and Katsura, I., 1964. Chemical composition of Hawaiian lavas. J. Petrol., 5:82-133.

Morgan, J., 1971. Convection plumes in the lower mantle. Nature, 230:42-43.

Schilling, J. G., Kingsley, R., Humphris, S. E., and Thompson, G., 1981. Tristan da Cunha hot spot. EOS, 62:424.

Schroeder, B., Thompson, G., Sulanowska, M., and Ludden, J. N., 1980. Analysis of geologic materials using an automated X-ray fluorescence system. X-ray Spectrometry, 9:198-205.

Skinner, N. G., Brown, F. W., and Flanagan, F. J., 1981. The $\mathrm{H}_{2} \mathrm{O}^{+}$ contents of some geochemical standards predicted by a calibration line. Geostandards Newsletter, 5:3-12.

Thompson, G., and Humphris, S. E., in press. Petrology and geochemistry of rocks from the Walvis Ridge: DSDP Leg 74, Sites 525, 527 and 528. In Moore, T. C., Jr., Rabinowitz, P. D., et al., Init. Repts. DSDP, 74: Washington (U.S. Govt. Printing Office).

Thompson, G., Humphris, S. E., and Schilling, J.-G., in press. Petrology and geochemistry of basaltic rocks from Rio Grande Rise, South Atlantic: Deep Sea Drilling Project Leg 72, Hole 516F. In Barker, P. F., Carlson, R. L., Johnson, D. A., et al., Init. Repts. DSDP, 72: Washington, D.C. (U.S. Govt. Printing Office).

Date of Initial Receipt: May 5, 1982 